\title{
INTERACTION OF OESTRADIOL AND NAFOXIDINE HYDROCHLORIDE WITH PROGESTERONE IN DECIDUOMATA FORMATION
}

\author{
G. W. DUNGAN, L. J. WYNGARDEN and J. G. GORNETte \\ Metabolic Diseases Research, The Upjohn Company, Kalamazoo, Michigan
}

(Received 28th October 1966, revised 18th May 1967)

\begin{abstract}
Summary. The effect of nafoxidine $\mathrm{HCl}$ and oestradiol on progesterone and oestradiol uptake by rat deciduomata was studied. Rats were ovariectomized and their uteri traumatized; they were subsequently injected for 4 days with $1.5 \mathrm{mg}$ of progesterone and either oestradiol $(0.005,0.05,0.1,0.5$ or $1.0 \mu \mathrm{g})$, or oestradiol $(0.05 \mu \mathrm{g})$ and nafoxidine $\mathrm{HCl}(0 \cdot 5,5,50,500,1000 \mu \mathrm{g})$. Tritiated oestradiol or progesterone was injected $4 \mathrm{hr}$ before killing the rats on the last day of treatment.

Uterine horns (traumatized and contralateral non-traumatized cornua) were removed and immediately prepared for the determination of radio-activity. Total non-volatile radio-activity and the radio-activity associated with the protein, ether-soluble and water-soluble fractions were determined. Ether soluble fractions were chromatographed on silica gel; areas associated with major steroid components were isolated and counted for radio-activity.

Both nafoxidine $\mathrm{HCl}$ and oestradiol effectively suppress the deciduomata response. The effects of each compound on the above parameters are not comparable in all cases. These differences, and their significance, are discussed.
\end{abstract}

\section{INTRODUCTION}

Nafoxidine $\mathrm{HCl}$, a representative of a series of dihydronaphthalenes and diphenylindenes, inhibits conception in laboratory animals. This antifertility efficacy is most likely due to an inhibition of implantation even though the compound can alter vaginal and oviduct physiology, and gonadotrophin secretion resulting in either inhibition or augmentation of ovulation (Duncan \& Forbes, 1965). In the pseudopregnant rat, traumatized uteri provide a suitable experimental means of approximating those decidual changes which occur in the uterus during the period of implantation of the blastocyst. The object of this study was to examine the effects of daily injections of different amounts of oestradiol on the uptake by deciduomata of radio-activity (tritiated oestradiol or progesterone) injected $4 \mathrm{hr}$ before autopsy, and to compare these effects with those observed after treatment with nafoxidine $\mathrm{HCl}$. 


\section{MATERIALS AND METHODS}

\section{Compounds}

Progesterone and oestradiol-17 $\beta$ were injected subcutaneously, at separate sites, each in $0.1 \mathrm{ml}$ of cottonseed oil containing $5 \%$ benzyl alcohol. Nafoxidine HCl, 1-\{2-[p-(3,4-dihydro-6-methoxy-2-phenyl-1-naphthyl)phenoxy] ethyl\}pyrrolidine hydrochloride, was injected subcutaneously in $0.5 \mathrm{ml}$ of sterile water containing $0 \cdot 25 \%$ methyl cellulose (Vehicle No. 122). In some instances tritiated steroids were included as part of the total dosage. Rats received either $150 \mu \mathrm{c}$ of progesterone- $7 \alpha-{ }^{3} \mathrm{H}$ (New England Nuclear Corporation, $1 \mu \mathrm{c} / 0 \cdot 017$ $\mu \mathrm{g}$ ) or $5.5 \mu \mathrm{c}$ of oestradiol-6,7- ${ }^{3} \mathrm{H}$ (New England Nuclear Corporation, $1 \mu \mathrm{c} /$ $0.009 \mu \mathrm{g}$ ). The steroids were chromatographed on paper before use; a single symmetrical peak of radio-activity was obtained with progesterone in the systems hexane : formamide, and iso-octane : $t$-butanol : methanol : water $(10: 2: 7: 1)$, and with oestradiol in propylene glycol-saturated-toluene:propylene glycol (1:1) (Reineke, 1956). Purity of the progesterone isotope was also demonstrated by isotope dilution employing two crystallizations from methanol.

\section{Deciduomata induction}

During pro-oestrus, adult virgin female Sprague-Dawley rats (200 to $250 \mathrm{~g}$ ) were placed with vasectomized males. The finding of a vaginal plug the next morning confirmed mating (Day 1 of the experiment). Vaginal smears were observed for the next 5 days to obtain evidence of pseudopregnancy. On Day 5 the left uterine horn of each rat was exposed by a mid-ventral incision and was traumatized by placing, and leaving in situ, a single piece of No. 3-0 silk suture thread, knotted at each end, throughout the length of the horn. The ovaries were removed at this time; the ovary on the contralateral side was removed by a lateral incision to minimize trauma to the right horn. At autopsy the rats were killed by cervical dislocation. Uteri were removed immediately, weighed and representative sections placed either in formalin for histological examination or on dry ice for subsequent biochemical analyses.

\section{Treatment}

Each rat received daily injections of progesterone $(1.5 \mathrm{mg})$ and either oestradiol $(0.005,0.05,0.1,0.5$ or $1.0 \mu \mathrm{g})$ or oestradiol $(0.05 \mu \mathrm{g})$ and nafoxidine $\mathrm{HCl}$ $(0.5,5,50,500$ or $1000 \mu \mathrm{g}$ ) from Day 5 (beginning $3 \mathrm{hr}$ after ovariectomy and traumatization) to Day 9. This sequence of treatment was used in each of two groups of rats: Group I received $150 \mu \mathrm{c}$ tritiated progesterone on the last day of treatment; Group II received $5.5 \mu \mathrm{c}$ tritiated oestradiol on the last day of treatment; $0.05 \mu \mathrm{g}$ oestradiol was, therefore, the minimum amount injected on this day.

Five rats were assigned at random to each treatment in each of the two groups and to blocks within each treatment. A sixth rat in each treatment did not receive any radio-active steroids and served as a control animal for background radio-activity determinations.

The experiment was designed and analysed as a 'split-plot' with the rats serving as whole units and the uterine horns representing sub-units. Due to the limited amount of non-traumatized tissue, some measurements were obtained 
only from the traumatized horn and the sub-unit analysis was not applicable. No transformation was applied to percentage data; all the other values were transformed to logarithms before statistical analysis. Except for uterine weight values, the statistical analyses of data of Group I animals were performed separately from those of Group II animals. Uterine weights from the two groups were pooled and analysed as a single study. Comparisons of the effect of nafoxidine $\mathrm{HCl}$ and of oestradiol treatment were made among the weights of the traumatized and of the non-traumatized horns.

\section{Analytical procedures}

Rats were killed $4 \mathrm{hr}$ after the last injection. Each uterine horn was weighed separately and segments were taken for dry weight determination and histological evaluation, and, from the non-traumatized horn, for the determination of radio-activity after combustion. The remainder of each traumatized horn was frozen immediately on dry ice and then homogenized in cold distilled water (125 $\mathrm{mg}$ tissue/ml water). Radio-activity of an aliquot $(2 \mathrm{ml}$ ) after combustion was determined and an amount $(25 \mu \mathrm{g})$ of either unlabelled progesterone (Group I) or oestradiol (Group II) was added to the remainder. Four volumes of absolute ethanol were added to the homogenate to precipitate protein at $-20^{\circ} \mathrm{C}$ overnight. After centrifugation the alcoholic solution was decanted, the precipitate washed with $5 \mathrm{ml}$ cold $80 \%$ ethanol and centrifugation repeated. The precipitate ('protein fraction') was then transferred to a tared combustion bag, dried, weighed and combusted. The combined supernatants were taken to dryness, the residue dissolved in water and extracted three times with an equal volume of ether. The combined ether extracts were washed with $1 / 10$ th volume of water, the 'aqueous fraction' dried and the residue taken up in $0.2 \mathrm{ml}$ water and counted in Diotol $(300 \mathrm{ml}$ toluene, $350 \mathrm{ml}$ dioxane, $210 \mathrm{ml}$ methanol, $73 \mathrm{~g}$ naphthalene, $50 \mathrm{ml}$ of Liquifluor, Pilot Chemicals, Inc., Mass.). One-tenth of the combined ether extract was evaporated to dryness and the residue taken up in Diotol and counted ('ether fraction'). The remainder of the ether extract was subjected to thin-layer chromatography (silica gel G, E. Merck Ag, 0.5 mm thickness, phosphors added) after adding $50 \mu \mathrm{g}$ of oestradiol to each preparation in Group II. Plates were developed in ether:methylene chloride, 2:5, for progesterone, or with benzene: ethanol, 9:1, for oestradiol, dried and scanned under u.v.-light. Appropriate silica gel bands were scraped off directly into Diotol for counting, and the radio-activity associated with the selected bands was reported as the percentage of the total radio-activity applied to each plate.

The various preparations were either added directly to Diotol $(15 \mathrm{ml})$ or first combusted by the Schoniger (1955) technique and then taken up in Diotol and counted in a Packard Tri-carb (Model No. 3003) liquid scintillation counter. All counts were corrected for quenching and for a counting efficiency of approximately $26 \%$.

\section{RESULTS}

Although these studies were run simultaneously, the results obtained in rats given daily injections of progesterone and oestradiol will be presented first, followed by those obtained with oestradiol and nafoxidine $\mathrm{HCl}$. 


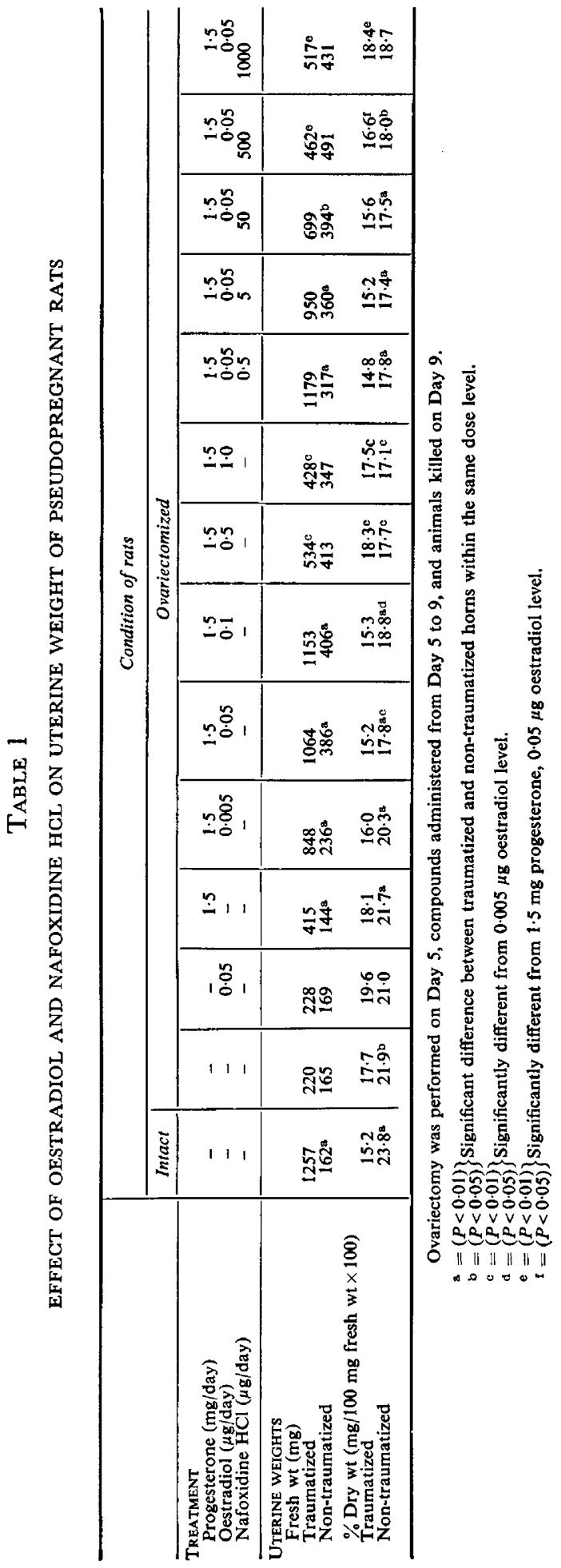




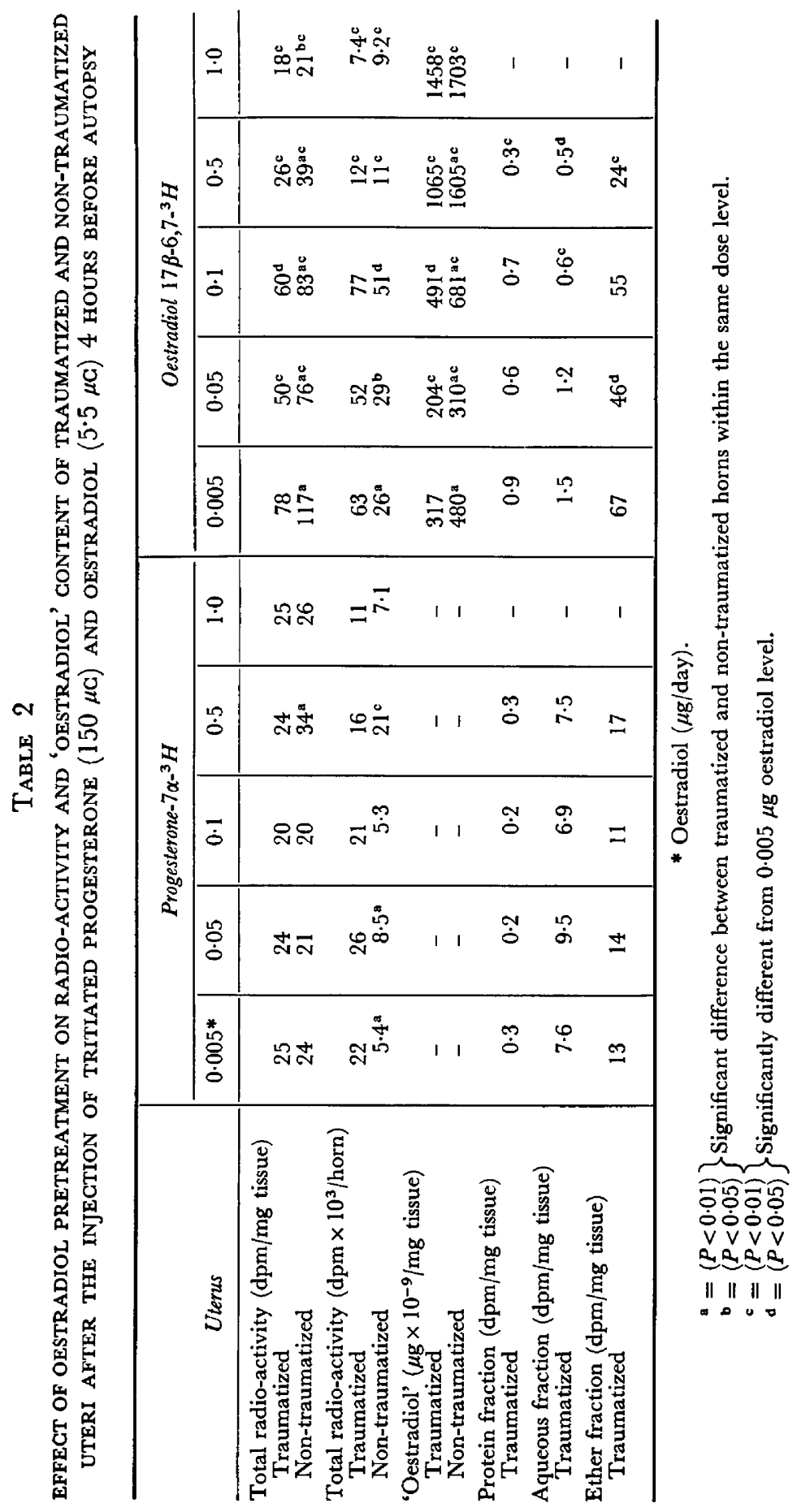


Oestradiol

Uterine weight. In ovariectomized rats oestradiol, in the absence of exogenously administered progesterone, did not effectively support a decidual response whereas daily treatment with $1.5 \mathrm{mg}$ of progesterone alone did produce a response (Table 1). Augmentation of this dose of progesterone with as little as $0.005 \mu \mathrm{g}$ of oestradiol had a synergistic effect on uterine weight responses; the maximum response occurred at doses between 0.05 and $0.1 \mu \mathrm{g}$ of oestradiol daily (progesterone : oestradiol ratio 15,000 to $30,000: 1$ ). This response was almost equivalent to that obtained by trauma of uteri in untreated intact pseudopregnant rats; the contralateral non-traumatized horns, however, were significantly heavier than those in intact rats. Further increases in the daily dose

\section{TABLE 3}

EFFEGT OF OESTRADIOL AND NAFOXIDINE HCL PRETREATMENT ON THE PERCENTAGE TOTAL RADIO-ACTIVITY IN FRACTIONS OF THE TRAUMATIZED UTERINE HORN AFTER INJECTION OF TRITIATED PROGESTERONE ( $150 \mu \mathrm{C}$ ) AND OESTRADIOL ( 5.5 $\mu$ C) 4 HR BEFORE AUTOPSY

\begin{tabular}{|c|c|c|c|c|c|c|c|c|c|c|}
\hline \multirow{3}{*}{$\begin{array}{l}\text { Uterine } \\
\text { fraction }\end{array}$} & \multicolumn{10}{|c|}{ Progesterone $-7 \alpha-{ }^{3} H$} \\
\hline & \multicolumn{4}{|c|}{ Oestradiol ( $\mu$ g/day) } & \multicolumn{6}{|c|}{ Nafoxidine $\mathrm{HCl}$ ( $\mu \mathrm{g} /$ day $)$} \\
\hline & 0.005 & 0.05 & $0 \cdot 1$ & 0.5 & $0 \cdot 0$ & 0.5 & $5 \cdot 0$ & 50 & 500 & 1000 \\
\hline $\begin{array}{l}\text { Protein } \\
\text { Aqueous } \\
\text { Ether }\end{array}$ & $\begin{array}{l}1 \cdot 3 \\
32 \\
54\end{array}$ & $\begin{array}{l}0 \cdot 8 \\
40 \\
57\end{array}$ & $\begin{array}{l}1 \cdot 2 \\
38 \\
53\end{array}$ & $\begin{array}{l}1 \cdot 2 \\
31 \\
66\end{array}$ & $\begin{array}{l}0 \cdot 8 \\
40 \\
57\end{array}$ & $\begin{array}{l}1 \cdot 0 \\
31^{b} \\
58\end{array}$ & $\begin{array}{l}2 \cdot 2 \\
34 \\
56\end{array}$ & $\begin{array}{l}1.6 \\
32 \\
76^{\mathrm{b}}\end{array}$ & $\begin{array}{c}1 \cdot 2 \\
25^{\mathrm{a}} \\
76^{\mathrm{b}}\end{array}$ & $\begin{array}{l}1 \cdot 2 \\
21^{2} \\
68\end{array}$ \\
\hline Total & 87 & 98 & 92 & 98 & 98 & 90 & 92 & 110 & 102 & 91 \\
\hline
\end{tabular}

\begin{tabular}{c|c|c|c|c|c|c|c|c|c}
\hline & \multicolumn{8}{c}{ Oestradiol-17 $\beta-6,7-{ }^{3} \mathrm{H}$} \\
\cline { 2 - 9 } $\begin{array}{c}\text { Uterine } \\
\text { fraction }\end{array}$ & \multicolumn{3}{|c|}{ Oestradiol $(\mu \mathrm{g} /$ day $)$} & \multicolumn{5}{|c}{ Nafoxidine $\mathrm{HCl}(\mu \mathrm{g} /$ day $)$} \\
\cline { 2 - 9 } & $0 \cdot 005$ & $0 \cdot 05$ & $0 \cdot 1$ & $0 \cdot 5$ & $0 \cdot 0$ & 0.5 & $5 \cdot 0$ & 50 & 1000 \\
\hline Protein & $1 \cdot 3$ & $1 \cdot 2$ & $1 \cdot 1$ & $1 \cdot 0$ & $1 \cdot 2$ & $1 \cdot 0$ & $0 \cdot 9$ & $1 \cdot 7$ & $5 \cdot 7^{\mathrm{a}}$ \\
Aqueeous & $2 \cdot 1$ & $2 \cdot 6$ & $1 \cdot 0$ & $2 \cdot 2$ & $2 \cdot 6$ & $1 \cdot 9$ & $1 \cdot 8$ & $6 \cdot 5^{\mathrm{a}}$ & $11^{\mathrm{a}}$ \\
Ether & 86 & 93 & 92 & 99 & 93 & 84 & 90 & 92 & 92 \\
Total & 89 & 97 & 94 & 102 & 97 & 87 & 93 & 100 & 109 \\
\hline
\end{tabular}

$\left.\begin{array}{l}\mathrm{a}=(P<0.01) \\ \mathrm{b}=(P<0.05)\end{array}\right\}$ Significantly different from control $(0.0 \mu \mathrm{g} /$ day nafoxidine $\mathrm{HCl})$.

of oestradiol above $0 \cdot 1 \mu \mathrm{g}$ depressed the deciduomata response. Since oestradiol also increased the weight of the contralateral non-traumatized horn, there was no significant difference in weight between the traumatized and non-traumatized horns at the higher $(0.5$ and $1.0 \mu \mathrm{g})$ dose levels.

Traumatization significantly decreased the uterine percentage dry weight. This difference between the two horns was also not significant at the two high doses of oestradiol.

Uterine radio-activity. With the exception of one inexplicable increase in the 
incorporation of progesterone- $7 \alpha-{ }^{3} \mathrm{H}$ into the non-traumatized horn at the 0.5 $\mu \mathrm{g}$ dose level, daily injections of oestradiol did not affect either the concentration or the distribution of radio-activity in either traumatized or non-traumatized horns (Table 2).

In contrast, daily injections of increasing amounts of oestradiol caused a nonlinear decrease in the concentration of radio-activity in both traumatized and non-traumatized horns in rats receiving tritiated oestradiol $4 \mathrm{hr}$ before autopsy (Table 2). The distribution of this radio-activity among the three tissue fractions was not significantly different (Table 3 ). The majority of the radio-activity in the other fraction was associated with the oestradiol area on the thin-layer chromatograms; there was, however, a significant change in the proportion of radio-activity associated with the steroid areas on the chromatogram at the 1.0 $\mu \mathrm{g}$ dose of oestradiol (Table 4). Daily injections of oestradiol did not significantly

\section{TABLE 4}

EFFECT OF OESTRADIOL AND NAFOXIDINE HGL PRETREATMENT ON PERCENTAGE DISTRIBUTION OF RADIO-AGTIVITY AFTER THIN-LAYER CHROMATOGRAPHY OF THE ETHER SOLUBLE FRAGTION OF TRAUMATIZED HORNS OF OESTRADIOL- $17 \beta-6,7-{ }^{3} \mathrm{H}$ TREATED RATS

\begin{tabular}{|c|c|c|c|c|}
\hline & \multicolumn{4}{|c|}{ Area of chromatogram } \\
\hline & Origin & Oestriol & Oestradiol & Oestrone \\
\hline $\begin{array}{l}\text { Oestradiol } \\
\text { ( } \mu \mathrm{g} / \text { day }) \\
0.005 \\
0.05 \\
0.10 \\
0.50 \\
1.00\end{array}$ & $\begin{array}{l}0.7 \\
2.5 \\
0.6 \\
1.6 \\
3 \cdot 4^{a}\end{array}$ & $\begin{array}{l}1 \cdot 0 \\
2 \cdot 1 \\
0 \cdot 9 \\
1 \cdot 4 \\
2 \cdot 1\end{array}$ & $\begin{array}{l}96 \cdot 6 \\
93 \cdot 1 \\
95 \cdot 2 \\
92 \cdot 7 \\
78 \cdot 5^{\mathrm{a}}\end{array}$ & $\begin{array}{l}0 \cdot 9 \\
1 \cdot 3 \\
3 \cdot 3 \\
2 \cdot 5 \\
6 \cdot 1^{\mathrm{a}}\end{array}$ \\
\hline $\begin{array}{c}\text { Nafoxidine } \mathrm{HCl} \\
(\mu \mathrm{g} / \text { day }) \\
0 \cdot 0 \\
0 \cdot 5 \\
5 \cdot 0 \\
50 \cdot 0 \\
500 \\
1000\end{array}$ & $\begin{array}{c}2.5 \\
1.3 \\
4.4 \\
1.5 \\
4.2 \\
12.4^{\mathrm{a}}\end{array}$ & $\begin{array}{c}2 \cdot 1 \\
1 \cdot 8 \\
2 \cdot 1 \\
2 \cdot 0 \\
3 \cdot 4^{\mathrm{a}} \\
11 \cdot 4^{\mathrm{a}}\end{array}$ & $\begin{array}{l}93 \cdot 1 \\
95 \cdot 3 \\
85 \cdot 7 \\
82 \cdot 0^{\mathrm{a}} \\
41 \cdot 6^{\mathrm{a}} \\
31 \cdot 8^{\mathrm{a}}\end{array}$ & $\begin{array}{c}1 \cdot 3 \\
1 \cdot 1 \\
3 \cdot 0 \\
8 \cdot 5^{\mathrm{a}} \\
21 \cdot 0^{\mathrm{a}} \\
16 \cdot 1^{\mathrm{a}}\end{array}$ \\
\hline
\end{tabular}

alter the distribution of radio-activity in the origin, progesterone, $20 \alpha$-hydroxypregn-4-en-3-one or cholesterol areas of the ether fraction from progesterone$7 \alpha-{ }^{3} \mathrm{H}$ treated animals; the percentage radio-activity in each area ranged from 8 to $21 \%, 57$ to $69 \%, 3$ to $7 \%$ and 7 to $9 \%$, respectively.

The amount of 'oestradiol' in the uterine tissue, calculated from the known specific activity of the administered dose and the amount of radio-activity per unit weight of tissue, was lower in the traumatized than in the non-traumatized horn at all but the highest dosage level (Table 2). There was substantially more 'oestradiol' per unit weight of tissue at the higher dosages even though these same doses significantly depressed uterine weight increases. 


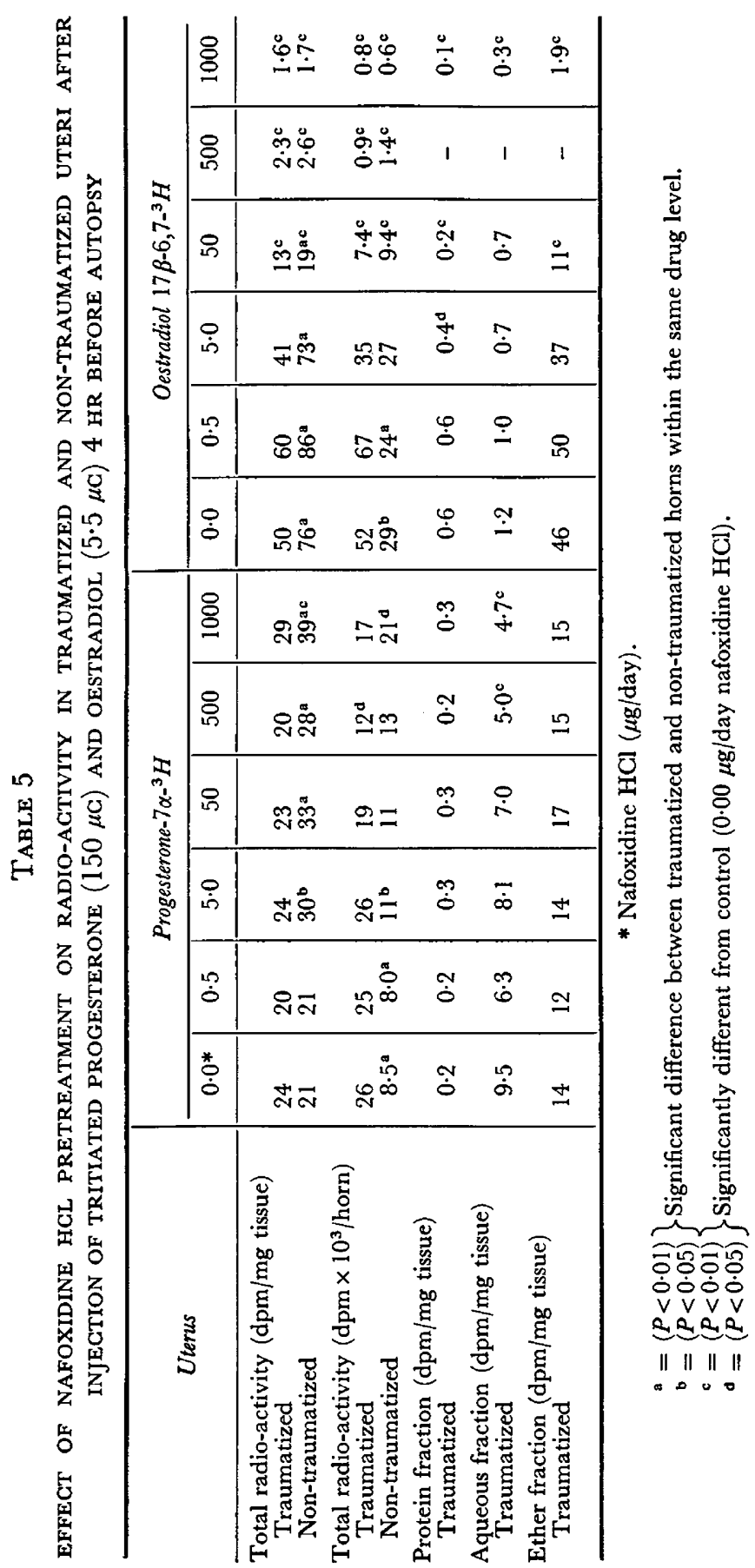




\section{Nafoxidine $\mathrm{HCl}$}

Uterine weight. The effects of nafoxidine $\mathrm{HCl}$ on deciduomata growth were similar to those observed for oestradiol. All animals in this group received a maintenance dose of $0.05 \mu \mathrm{g}$ of oestradiol and $1.5 \mathrm{mg}$ of progesterone in addition to different doses of nafoxidine $\mathrm{HCl}$ (Table 1). There was a dose-dependent decline in the weight of the traumatized horns over the range of doses studied. The weight of the non-traumatized horn was not significantly altered by increasing doses of nafoxidine $\mathrm{HCl}$. At the two highest doses, the weights of the two horns were similar.

Nafoxidine $\mathrm{HCl}$ increased the percentage dry weight of the traumatized horn significantly at doses of 500 and $1000 \mu \mathrm{g}$. At the highest dose level there was no significant difference between the percentage dry weight of the traumatized and non-traumatized horns.

Uterine radio-activity. After the administration of tritiated progesterone to rats previously injected every day with nafoxidine $\mathrm{HCl}$, the incorporation of radioactivity into the non-traumatized horn was significantly increased at doses above $0.5 \mu \mathrm{g}$ (Table 5). Although there was no significant change in the total radioactivity concentration of the traumatized horn, there was a slight but significant decline in the concentration of radio-activity associated with the aqueous fraction. This alteration in the distribution of radio-activity was more apparent when the radio-activity of the various fractions was calculated as a percentage of total radio-activity present (Table 3 ). The amount of activity in the tissues was relatively low and, although these changes are statistically significant, it is difficult to ascribe any biological significance to them. In the ether phase there was no significant change in the distribution of radio-activity in the origin, progesterone, 20 $\alpha$-hydroxypregn-4-en-3-one or cholesterol areas on the thinlayer chromatograms; the activity ranged from 8 to $16 \%, 61$ to $71 \%, 3$ to $7 \%$ and 6 to $11 \%$, respectively.

After the administration of tritiated oestradiol, the concentrations of radioactivity in both uterine horns decreased as the dose of previously injected nafoxidine $\mathrm{HCl}$ was increased above $5 \mu \mathrm{g} /$ day (Table 5 ). The differences in radioactivity concentrations between the two horns with the lower doses was eliminated with the high doses. The decline in tritium uptake was evident in each of the tissue fractions analysed.

Although the reduction in the amount of total radio-activity associated with the uterine tissue at the higher doses of nafoxidine $\mathrm{HCl}$ was very dramatic, the distribution of the radio-activity among the three fractions was not altered in the same way. There was a significant increase in the proportion of material present in the aqueous and protein fractions (Table 3), but these together accounted for only about $10 \%$ of the total radio-activity present in the traumatized horn. Of greater interest was the ether-soluble or free steroid fraction. It contained approximately $90 \%$ of the total uterine radio-activity and when subjected to thin-layer chromatography the proportion of radio-activity in the oestradiol area showed a decline as the dose of nafoxidine $\mathrm{HCl}$ was increased (Table 4). There were similar increases in the amounts of labelled material at the origin, in the oestriol and oestrone areas and, not shown in the table, associated with the solvent front. 


\section{DISCUSSION}

Dosages of oestradiol in excess of the amount supporting maximum deciduomata weight inhibited, as would be anticipated, deciduomata development. The concentration of 'oestradiol' in the uterus increased, however, as the dose was increased; the traumatized uterus sequestered oestradiol in amounts far in excess of that required for normal growth responses. The decline in the proportion of the administered dose of oestradiol incorporated into the traumatized uterus suggests the presence of saturable binding sites; similar to the condition observed by Eisenfeld \& Axelrod (1965) when studying the uterotrophic response of oestradiol in rats. If an active transport process for oestradiol exists, its capacity is far in excess of the requirements for maximum deciduomata development. This is in contrast to the uterotrophic response in which the saturation level and the maximum uterotrophic doses are closer to each other (Terenius, 1965).

Dihydronaphthalenes alter a number of oestrogen response processes in laboratory animals. Depending upon the particular response being observed, these effects have been ascribed to oestrogenic, 'impeded oestrogenic' or 'oestrogen-antagonistic' properties. In the present study, rats were ovariectomized at the time of traumatization and subsequently subjected to progesterone and oestradiol treatment. In this way it was possible to assess the effect of nafoxidine $\mathrm{HCl}$ on deciduomata responses in the absence of changes in ovarian steroid secretion and also to assess, under comparable conditions, the effect of different doses of exogenous oestradiol. A comparable and essentially maximal suppression of deciduomata growth was achieved with $0.5 \mu \mathrm{g}$ of oestradiol and with 500 $\mu \mathrm{g}$ of nafoxidine $\mathrm{HCl}$. Oestradiol can be visualized as acting as its own competitive inhibitor over the dose range investigated. Nafoxidine $\mathrm{HCl}$ and oestradiol appear to be equally effective in inhibiting uterine weight. In contrast to oestradiol, however, (when compared over a range of dosages causing similar degrees of inhibition of deciduomata growth), nafoxidine $\mathrm{HCl}$ altered the incorporation (into the non-traumatized horn) and the distribution of radio-activity after the injection of tritiated progesterone, and the distribution and metabolic pattern of radio-activity after the injection of tritiated oestradiol. The pattern of inhibition resulting from nafoxidine $\mathrm{HCl}$ treatment was not identical to that observed with excessive doses of oestradiol.

Progesterone and cortisol also antagonize the effects of oestradiol on uterine and decidual tissue but, in contrast to nafoxidine $\mathrm{HCl}$, by mechanisms not involving oestradiol uptake (Lerner, 1964; Jacobson, Smith, Colucci \& Jensen, 1964). Similarly, $5(\alpha, \alpha, \alpha$-trifluoro- $m$-tolyloxymethyl)-2-oxazolidinethione effectively inhibits deciduomata development without altering either progesterone- $7 \alpha-{ }^{3} \mathrm{H}$ or oestradiol- $17 \beta-6,7-{ }^{3} \mathrm{H}$ incorporation into traumatized uterine tissue (Duncan, Cornette, Lyster, Northam \& Wyngarden, 1966). Interestingly, this latter compound is inactive in the classical steroidal and antisteroidal hormone assays (Duncan, Johnston \& Lyster, 1966).

Oestradiol, nafoxidine $\mathrm{HCl}$ and the oxazolidinethione each inhibit deciduomata development. At doses affording maximum suppression of weight response, oestradiol and nafoxidine $\mathrm{HCl}$ alter oestradiol accumulation in the 
traumatized as well as in the non-traumatized horn. The oxazolidine is without effect on oestradiol or progesterone uptake and does not cause any weight increments in the non-traumatized horn. In contrast to oestradiol, nafoxidine $\mathrm{HCl}$ alters progesterone incorporation and may have a more marked effect on metabolism of the ether-soluble oestrogens. Thus, although the gross effect of each of these compounds on deciduomata growth is comparable, the effects of these compounds on the reproductive tract and on other organs would be quite different. Appropriate oestrogen antagonists or 'impeded oestrogens' could, therefore, possibly play an effective role as pregnancy inhibitors where oestrogen-related side effects preclude the use of oestrogens.

\section{ACKNOWLEDGMENTS}

The authors are indebted to Dr J. R. Schultz for his assistance in the experimental design of this study and for his statistical analyses of the resulting data and to Dr D. Lednicer for the synthesis of nafoxidine HCl (Lednicer, Babcock, Lyster \& Duncan, 1963).

\section{REFERENCES}

Duncan, G. W., Gornette, J. C., Lyster, S. C., Northam, J. I. \& Wyngarden, L. J. (1966) Biochemical aspects of rat deciduomata as affected by an oxazolidinethione. Am. F. Physiol. 211, 184.

Duncan, G. W. \& Forbes, A. D. (1965) Blastocyst survival and nidation in rats treated with oestrogen antagonists. F. Reprod. Fert. 10, 161.

Duncan, G. W., Johnston, R. L. \& Lyster, S. C. (1966) Inhibition of pregnancy with an oxazolidinethione (U-1 1634). F. Reprod. Fert. 11, 85.

Eisenfeld, A. J. \& Axelrod, J. (1965) Selectivity of estrogen distribution in tissues. J. Pharmac. exp. Therap. 150, 469 .

Jacobson, H. I., Smith, S., Colucci, V. \& Jensen, E. V. (1964) Effect of anti-uterotropic agents on uptake of estradiol by rat tissues. Endocrine Society Meeting, Abstract 31, San Francisco, California.

Lednicer, D., Babcock, J. C., Lxster, S. C. \& Duncan, G. W. (1963) Derivatives of 1,2-diphenyl-3,4dihydronaphthalene as antifertility agents. Chemy Ind. 408.

Lerner, L. J. (1964) Hormone antagonists: Inhibitors of specific activities of estrogen and androgen. Recent Prog. Horm. Res. 20, 435.

Rerneke, L. M. (1956) Paper chromatography in steroid determination. Analyt. Chem. 28, 1853.

SCHONIGER, W. (1955) Eine mikroanalytische Schnellbestimmung von Halogen in organischen Substanzen. Mikrochim. Acta, 1, 123.

Terenius, L. (1965) Uptake of radioactive oestradiol in some organs of immature mice. Acta endocr., Copenh. 50, 584. 